\title{
The Increase of Organizational Citizenship Behaviour (OCB) Through Islamic Work Ethics, Affective Commitment, and Organizational Identity
}

\author{
Wuryanti Kuncoro ${ }^{1}$, Gunadi Wibowo ${ }^{1}$ \\ ${ }^{1}$ Economics Faculty, Universitas Islam Sultan Agung Semarang, \\ Correspondence: Wuryanti Kuncoro, Economics Faculty, Universitas Islam Sultan Agung Semarang, Indonesia.
}

Received: December 20, 2018

Accepted: January 21, 2019

Online Published: January 29, 2019

doi:10.5539/ibr.v12n2p181

URL: https://doi.org/10.5539/ibr.v12n2p181

\begin{abstract}
An employee who is willing to voluntarily help fellow co-workers to do work outside the assigned job description and the assistance provided is not included in the performance assessment, can be defined as organizational citizenship behavior (OCB). Podsakoff et.al (2000) states that OCB can influence organizational effectiveness because it can help improve co-workers productivity, increase managerial productivity and streamline the use of organizational resources for productive purposes. This research was conducted to identify the effect of Islamic work ethics, affective commitment and organizational identity on OCB. The data were collected from 110 employees at the Muhammadiyah Islamic Hospital of Kendal and the Muhammadiyah Darul Istiqomah Hospital of Kendal. The data were later analyzed using Structural Equation Modeling (SEM) using the Analysis of Moment Structure (AMOS 24) software. The result indicates that affective commitment and organizational identity have a significant effect on OCB while Islamic work ethics have no significant effect on OCB. The researcher hopes that this research can be developed in future research by adding other variables related to OCB that may have a greater influence on OCB.
\end{abstract}

Keywords: OCB, Islamic work ethics, affective commitment, organizational identity

\section{Introduction}

Today, very sharp competition occurs in the business world. Many things can be the trigger factors for these conditions, including the effects of globalization, the rapid development of science and technology. To deal with these conditions, organizations that want to maintain their business continuity or maintain their growth will increasingly depend on how the organization manages its human resources (HR) to gain a competitive advantage.

For the community, the existence of a hospital founded by an Islamic community organization which can be defined as an Islamic hospital becomes something that encourages and makes a proud and also expected that it had superior human resources and could implement Islamic work ethics in every field of service. Ali and Al-Owaihan (2008) stated that Islam provides a specific perspective on "work" and the manifestation of a specific concept of work ethics, namely Islamic work ethics.

By practicing Islamic work ethics, it is expected to improve OCB behavior among HR. OCB stands for Organizational Citizenship Behavior is defined as the someone's work behavior who volunteered to help and do work that is not contained in the description of the assignment that has been set for him. Podsakoff et al. (2000) stated that OCB can increase organizational effectiveness because it can help increase the productivity of coworkers, increase managerial productivity and streamline the use of organizational resources for productive matters.

Several previous studies have shown the relevance of Islamic work ethics towards OCB. Fakhar et.al (2012) conducted research on HR of government hospital and bank in Pakistan. The result of his research showed that there is a positive and significant influence of Islamic work ethics on OCB. Alhyasat (2012) in his research found a high level of commitment of some HR in the Jordan Press Foundation to Islamic work ethics. There are significant effects of several dimensions of Islamic work ethics on OCB while some other dimensions of Islamic work ethics do not significantly influence OCB. 
Besides that, in order to facilitate achieving organizational goals, employees' management by organizations needs to pay attention to employees' commitments. In addition to having good and quality work behavior, employee must be committed to the organization. Organizational commitment is classified into three types, namely affective, normative, and continuous commitment. From these three types, affective commitment becomes the most beneficial for the company because employees with high affective commitment tends to feel confident with the company so that it will try optimally to improve the work quality for the achievement of organizational goals (Kusumastuti and Nurtjahjanti, 2013).

The study result of the Nizam et al. (2016) on 156 respondents from several small and medium enterprises (SME) in textile trade in Selangor, Kuala Lumpur, and Johor (Malaysia) proved that the application of high Islamic work ethics would result in high organizational commitment and showed that the application of Islamic work ethics can help realize a large commitment to the organization. The research of Nizam et.al (2016) also shows the existence of a significant and positive relationship between Islamic work ethics and affective commitment. The study result of Subejo et.al (2013) on firefighter in the Jakarta Provincial Government showed that organizational commitment had a significant effect on OCB.

Organizational identity is basically a reflection of the organizational image. It is also defined as a reflection of organizational culture and serves to increase the effectiveness of organizations in adjusting to the demands of the environment (Himam, 2012). Organizational identity will create the motivation needed to arouse volunteerism in organizational behavior (Prasetyo and Himam, 2013).

The study result of Fakhar et al. (2012) suggest that further research can be carried out on private sector companies and can add other variables to study. This attracted researchers to conduct research on the influence of Islamic work ethics on OCB. Researchers are also interested in examining the influence of Islamic work ethics on the affective commitment which becomes a part of the organizational commitment. Researchers choose affective commitment because it is an important factor that determines employees' dedication and loyalty as stated by Rhoades et.al (2001). The researcher will also examine the effect of affective commitment and organizational identity on OCB.

There are several health facilities in Kendal, Central Java, Indonesia that was established and owned by Islamic community organizations. Meanwhile, there are 2 Islamic hospitals that are quite well known by the Kendal society and its surroundings, namely Muhammadiyah Islamic Hospital of Kendal (RSI) and Muhammadiyah Darul Istiqomah Hospital of Kendal (RSDI). Both of these hospitals are relatively identical because they were established and owned by Muhammadiyah Association (Indo: Persyarikatan Muhammadiyah).

The satisfaction survey by Quality Management Representative (QMR) conducted on inpatient patients in January 2018 showed that $9 \%$ of patients were dissatisfied with the condition of the bathroom/toilet and 5.9\% were dissatisfied with the condition of the patient waiting room. While the survey in February 2018 showed that $8.1 \%$ of patients were dissatisfied with the condition of the bathroom/toilet and $5.2 \%$ were dissatisfied with the condition of the patient waiting room. Rodhiyatun et. al. (2014) stated that the result of the satisfaction survey in September 2013 by the QMR of RSI on inpatient patients showed that 55\% of patients were satisfied, $11.5 \%$ were satisfied but $15 \%$ of patients expressed dissatisfied. From ten respondents there are four people who complained regarding daily interactions in the hospitalization environment. There were also two respondents who complained about interpersonal health personnel and three respondents who complained regarding nursing services.

This illustrates that there is still dissatisfaction from patients even though from observations and information from the community, the RSI has become the community choice not only in Kendal, Central Java, Indonesia but also in Batang Central Java, Indonesia. According to the community, RSI and RSDI have good respect and have their own peculiarities related to the application of Islamic work ethics in their service activities.

Based on the description above, researchers are interested in examining the level of commitment of RSI and RSDI on Islamic work ethics and the effect of applying Islamic work ethics on affective commitment, organizational identity, and OCB. The researchers will also examine the effect of affective commitment and organizational identity on OCB. Therefore, this research is entitled 'the increase of OCB through Islamic work ethics, affective commitment, and organizational identity'.

\section{Literature Review}

\subsection{Islamic Work Ethics}

Work ethics is defined as a collection of values, traits, attitudes, and behaviors about how people do or handle their work. Islam strongly demands that its adherents have strong moral values and follow the Islamic teachings 
in carrying out their work to seek the pleasure of Allah SWT, which becomes the ultimate goal in life (Zahrah et.al, 2016).

Ahmad and Owoyemi (2012) define Islamic work ethics as a set of values or belief systems sourced from the Qur'an and Sunnah regarding work. According to Ali and Al-Owaihan (2008), Islamic work ethics is an orientation that directs and influences Muslim involvement and participation in the working world. At workplace, Muslims are expected to know what is right and wrong based on Islamic teachings and behave and act in accordance with Islamic teachings (Zahrah et.al, 2016).

From the several definitions above, it can be concluded that Islamic work ethics is a set of values or belief systems based on the Qur'an and Sunnah of the Prophet Muhammad that is held by members of the organization that animates every thought, speech and action or behavior.

Alhyasat (2012) states that there are nine dimensions of Islamic work ethics, namely proficiency, kindness and forgiveness in dealing with employees, advice to Muslims and creativity in services, sense of responsibility, fairness and justice, integrity, teamwork, obedience, observing dignity and honor of the profession.

\subsection{Affective Commitment}

According to Hidayat (2010), organizational commitment can be divided into three types who have a different level or degree. These three types of organizational commitment are:

- Continuance commitment is a commitment based on the members' perceptions of the losses they will receive if they leave the organization or the benefits to be gained if they maintain their membership. So that this commitment remains in the organization based on the consideration of the profit and loss earned.

- Normative commitment is a commitment that includes members' feelings regarding the obligations and responsibilities that must be given to the organization so that members remain in the organization because they feel obliged to be loyal to the organization.

- Affective commitment related to emotional, identification and involvement of members in the organization so that it has an emotional attachment to the organization that is seen in involvement and feeling happy and enjoying their role in the organization.

Affective commitment is formed from organizational efforts to make employees have strong beliefs to follow all organizational values (Han et al., 2012). Affective commitment is an important factor that determines the employees' dedication and loyalty. Employee with high affective commitment tends to show ownership of the organization, experience increased participation in organizational activities, the desire to achieve organizational goals, and the desire to remain a member of the organization (Rhoades et.al, 2001).

Kusumastuti and Nurtjahjanti (2013) stated that effective commitment was valued higher than normative and continuous commitment, while normative commitment was valued higher than continuous/rational commitment so that employees who had affective commitment would be more valuable to the organization because they have already involved emotional factors which will then work with feelings of pleasure and enjoy their role in the organization.

From several definitions above, it can be concluded that affective commitment is a strong desire to remain a member of an organization with emotional attachments reflected through feelings of pleasure, involvement, enjoying the role and acceptance of organization values and goals.

The indicators used in the affective commitment variable based on the research used by Rhoades et.al (2001) are as follows:

- Has a deep personal meaning.

- A strong sense of belonging with the organization.

- Proud to tell others about the organization.

- Bound emotionally with the organization.

- Glad to be able to work in the organization until retirement.

- Feel that the problem faced by the organization becomes their problem too.

There are several antecedents of affective commitment that have been identified including personal characteristics, structural characteristics, characteristics related to work, and work experience, where work experience has the strongest and most consistent relationship (Han et al., 2012). 
The study result of the Nizam et.al (2016) on 156 respondents from several small and medium enterprises (SMEs) in Selangor, Kuala Lumpur, and Johor (Malaysia) proved that Islamic work ethics had a significant and positive influence on affective commitment to the hypothesis proposed was:

H1: Islamic work ethics has a significant effect on affective commitment.

\subsection{Organizational Identity}

Organizational identity is basically a reflection of the organizational image, culture and serves to increase the effectiveness of organizations in adjusting to the environment demands (Himam, 2012). Organizational identity is similar to an organization's self-image which is defined as organizational characteristics that are "central, enduring, and distinctive" (Himam, 2012).

Organizational identity develops as a shared understanding of organizational members regarding the characteristics of an organization that has important, relatively permanent, and can be used as a differentiator with other organizations. This shared understanding arises as an interpretation of the values that develop in the organization and it becomes the result of the social reconstruction and interaction process (Himam, 2012).

From several definitions above, it can be concluded that organizational identity is a reflection of the organizational image and culture that emerges as an interpretation of the values that develop in the organization and it becomes the result of social reconstruction and interaction process of organizational members and serves to increase organizational effectiveness in adjusting to the environment demands.

Prasetyo and Himam (2013) explain organizational identity as a unit of six aspects contained in the organization, namely: (1) actual identity is a special attribute that is owned by the organization at present which can be seen such as in the business segment, organizational goals, ethos and work style, and market segments; (2) communicated identity is a message conveyed by the organization through communication to outside parties either through logos, advertisements and public relations; (3) conceived identity is related to the organizational description and reputation in the minds of customers and other stakeholders; (4) covenanted identity is related to the principal message implied in the organizational name and or logo; (5) ideal identity refers to the ideal organizational identity or positioning as expected; (6) desired identity is related to the desires of the owners and leaders of the organization in the long time period.

The realtionship between Islamic work ethics and organizational identity can be seen from the notion that Islamic work ethics is a set of values or belief systems based on the Qur'an and Sunnah of the Prophet Muhammad that is held by organizational members who inspire every thought, speech and action or behavior.

These values then develop an organizational identity as a collective understanding of organizational members on the characteristics of organizations that are important, relatively permanent, and are distinguishing between one organization and another (Himam, 2012). So the hypothesis proposed is:

H2: Islamic work ethics has a significant effect on organizational identity.

\subsection{Organizational Citizenship Behaviours (OCB)}

The concept of OCB was first formally conveyed by Chester Barnard as the willingness of individuals in organizations to work together (Harper, 2015). OCB is defined as discretionary individual behavior. It is not rewarded by a formal reward system and can increase the effectiveness of organizational functions. It is free and voluntary because such behavior is not required by the requirements of the role or description of the task which is clearly determined based on an agreement with the organization but it becomes an individual choice (Podsakoff et.al, 2000).

Allameh et al. (2012) mention four characteristics of OCB as follows:

- Activities carried out are not specified work activities.

- Activities are carried out because of personal motivation.

- This behavior is not formally defined or clearly stated in the formal reward system.

- This behavior helps the whole organization but it is not evaluated in the system of effectiveness.

Based on the information above, it can be concluded that OCB is the individual behavior outside of the job description and it is not formally determined in a reward system that is done voluntarily and contributes to the increase in effectiveness and efficiency in the organization.

Podsakoff et al. (2000) propose 7 (seven) OCB dimensions, namely: 
- Helping Behavior defines as helping other people voluntarily and always being vigilant in anticipation of possible problems related to work.

- Sportsmanship is the ability to tolerate poor treatment from colleagues by not complaining and still showing a positive attitude, or even willing to sacrifice personal desires for the good of the organization.

- Organizational Loyalty refers to promote organization to outsiders, protect and defend organization from external threats and commit themselves to organization despite unfavorable conditions.

- Organizational Compliance is individual acceptance of organizational rules and policies that is realized by adhering to these rules and policies even if no one is watching.

- Individual Initiative defines as individual who has more initiative, for example, someone will ask if he or she do not understand their work, or do his or her work without having to wait to be ordered beforehand.

- Civic Virtue is the great interest or commitment to the organization as a whole that is indicated by the desire to actively participate in organizational governance (e.g. attending meetings, participating in policy discussions, conveying ideas), paying attention to environmental conditions to find out threats and opportunities for organizations, and seek opportunities to always do good (e.g. reporting fire or suspicious activity).

- Self Development refers to voluntarily take action in the context of self-development by improving abilities, skills, and knowledge.

Abbasi and Rana (2012) stated that OCB improves the individual and organizational performance. The cultural component of OCB is organizational-specific and depends on the organizational values, beliefs and work ethics.

Fakhar et.al (2012) conducted a study on 165 employees in 15 government hospitals and 8 private banks in Pakistan. He found that Islamic work ethics had a positive and significant influence on OCB and both variables had a strong relationship so that it could be concluded that the higher Islamic work ethics will increase OCB. So the hypothesis proposed is:

H3: Islamic work ethics has a significant effect on OCB.

The study result of the Subejo et.al (2013) on 355 fire brigades in the Jakarta Provincial Government showed that these three dimensions or types of organizational commitment had a significant effect on OCB so that the hypothesis proposed is:

H4: Affective commitment has a significant effect on OCB

Prasetyo and Himam (2013) argue that organizational identity will create the motivation needed to arouse volunteerism in organizational behavior.

Amini et al. (2016) conducted a study of the tax employees in Lorestan, Iran with a sample size of 250 respondents. The result of his research indicates that organizational identity has an influence on OCB so the hypothesis proposed is:

H5: Organizational identity has a significant effect on OCB.

\subsection{Empirical Model}

The empirical model of this study is as follows:

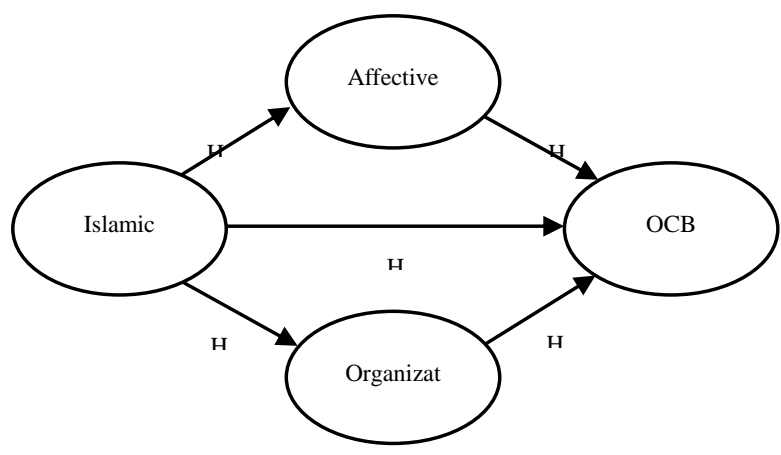

Figure 1. Empirical Model of Research 


\section{Research Methodology}

\subsection{Population and Sample}

The population of this study is all RSI employees that is 459 people and RSDI employees are 145 people so that the population is amounted 604 people. The sampling used in this study is proportional random sampling (Wahyudi, 2012) because it involves several subgroups. Ghozali (2017: 62) recommends that sample sizes between 100 and 200 must be used for Maximum Likelihood Estimation (ML). In this study, 130 questionnaires were distributed (22\% of the total population), namely 100 questionnaires in RSI (22\% of total RSI employees) and 30 questionnaires in RSDI (21\% of total RSDI employees). From 100 questionnaires distributed at the RSI, 84 questionnaires (84\%) were collected. Whereas 30 questionnaires distributed in RSDI collected 26 questionnaires (87\%) then the answers from 110 respondents (85\%) can be analyzed.

\subsection{Data Collection Technique}

Data collection techniques of this study are:

- Observation

Direct observation or observation is intended to obtain a clear picture of the situation and activities carried out by the RSDI and RSDI employees.

- Questionnaires Distribution

This becomes a method of collecting data directly which is done by submitting a list of questions to the respondents. The questionnaire was submitted directly to the respondent and returned to the researcher within 7 days after questionnaire given.

\subsection{Operational Variable and Indicator Definition}

Islamic work ethics is a set of values or belief systems based on the Qur'an and Sunnah of the Prophet Muhammad about work that animates every thought, word and work behavior of employees. The indicators of the variable Islamic work ethics in this study cite six of the nine dimensions of Islamic work ethics according to Alhyasat (2012), namely proficiency, kindness, responsibility, fairness, and teamwork.

Affective Commitment is the desire or attitude to stay in organization because of the suitability of values and emotional attachments. The variable indicators of affective commitment used in this study cite five of the six indicators of affective commitment delivered by Rhoades et al. (2001), they are highly meaningful organizations, belonging, pride, emotional attachment, and loyalty.

Organizational Identity is a reflection of the organizational image in the minds of employees that distinguishes it from other organizations. These variable indicators cite three of the six aspects of organizational identity conveyed by Prasetyo and Himam (2013), they are organizational specific attributes, external communication, and organizational reputation.

OCB is voluntary behavior that is not included in formal duties and is considered to contribute to increasing effectiveness and efficiency in the organization. The OCB variable indicators used in this study cite six of the seven dimensions of OCB proposed by Podsakoff et al. (2000), namely helping behavior, sportsmanship, organizational loyalty, organizational compliance, individual initiative, and responsiveness.

\subsection{Data Analysis Technique}

To test the model and hypothesis, this study used SEM (Structural Equation Modeling) analysis by using Analysis of Moment Structure (AMOS 24) program.

\section{Findings}

\subsection{Conformity and Stastical Test}

Based on the suitability index and the cut-off value if the suitability index $\geq$ or $\leq$ than cost of value that is used to test whether a model is accepted or rejected as stated by Ferdinand (2005) as a whole it can be seen in the following table 1: 
Table 1. Model Feasibility Index (Goodness-Of-Fit Index)

\begin{tabular}{|c|c|c|c|c|}
\hline Goodness of Fit Index & Cut-of-Value & $\begin{array}{c}\text { Analysis } \\
\text { Result }\end{array}$ & Evaluation Model & Conclution \\
\hline $\mathrm{X}^{2}$ Chi-Square & Small Expected & 445,051 & & \\
\hline Significance & $\geq 0,05$ & 0,000 & Marginal & The result value accepted as marginal \\
\hline Probability & & & & \\
\hline RMSEA & $\leq 0,08$ & 0,136 & Marginal & The model is well \\
\hline GFI & $\geq 0,90$ & 0,715 & Marginal & The result value is adequate fit it can use \\
\hline AGFI & $\geq 0,90$ & 0,631 & Marginal & The result value is better fit \\
\hline CMIN/DF & $\leq 2,00$ & 3,028 & Marginal & $\begin{array}{l}\text { The result value acceptable fit as } \\
\text { marginal }\end{array}$ \\
\hline TLI & $\geq 0,95$ & 0,892 & Marginal & The result value almost good fit \\
\hline CFI & $\geq 0,95$ & 0,907 & Marginal & The result value very good fit \\
\hline
\end{tabular}

Source: Primary Data Source, 2018

\subsection{Validity Test}

A dimension indicator shows significant convergent validity if the indicator variable coefficient is greater than twice the standard error (Ferdinand, 2005: 304).

Based on AMOS text output on regression weight, it shows that all indicators produce a critical ratio estimation value that is greater than twice the standard error, it can be concluded that the indicator variable used is valid. This shows that the indicator validly measures what should be measured in the model presented.

\subsection{Realibility Test}

Basically, the reliability test shows the extent to which a measuring instrument can provide result that is relatively the same if measurements are taken again on the same subject. The recommended approach in reliability test is to assess the reliability of composite quantities and extracted variance from each construct (Ferdinand, 2005: 93).

\section{- Composite (Construct) Reliability}

The value of construct reliability sequentially for the variables of Islamic work ethics, affective commitment, organizational identity, and OCB are $0.979 ; 0.929 ; 0,969 ; 0.936$. it is known that the reliability value is $\geq$ 0.70 for all variables so that this data is feasible to use.

\section{- Variance Extracted}

The value of variance extracted sequentially for the variables of Islamic work ethics, affective commitment, organizational identity, and OCB are $0.901 ; 0.725 ; 0.913 ; 0.713$. It is known that the extracted variance value is $\geq 0.50$ for all variables so that it can be stated that this data is feasible to use.

\subsection{Estimated Structural Equation Model}

After the model is analyzed using confirmatory factor analysis and it can be proven that each indicator can define latent constructs, then a full SEM model can be analyzed. The result of processing using AMOS can be seen in Figure 2.

SEM of The Increase of OCB, through Islamic Work Ethics, Affective Commitment, and Organizational Identity

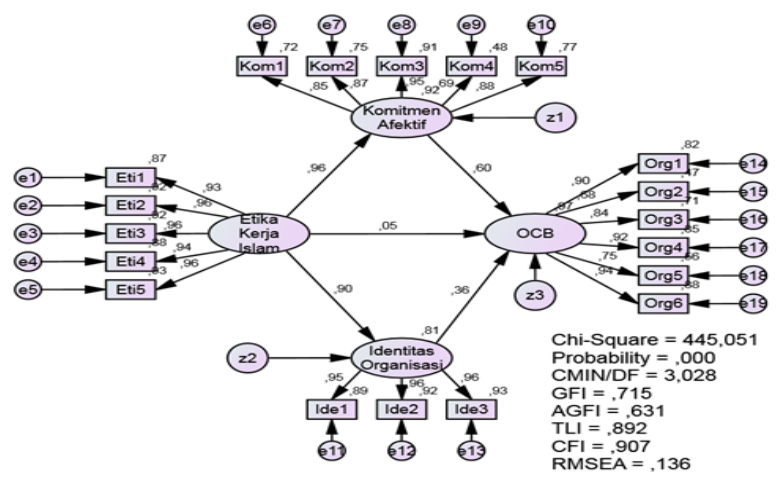

Figure 2. Full Structural Model 


\subsection{Hypothesis Test}

Hypothesis test that has been proposed is done by looking at the value of CR at regression weights on AMOS text output. If the critical ratio (CR) of an estimate or coefficient $\geq 2$, it can be concluded that the resulting regression coefficient is significant (Ferdinand, 2005: 37).

The whole acceptance and rejection of the hypothesis are presented in the following table 2 :

Table 2. The Acceptance and Rejection of Hypothesis

\begin{tabular}{|c|c|c|c|c|}
\hline \begin{tabular}{|c|} 
Hypothesis \\
\end{tabular} & C.R. & Cut of Value & Significance & Conclusion \\
\hline $\begin{array}{l}\text { Islamic work ethics has a } \\
\text { significant effect on affective } \\
\text { commitment }\end{array}$ & 13,730 & 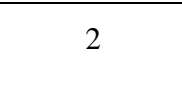 & Significance & Accepted \\
\hline $\begin{array}{l}\text { Islamic work ethics has a } \\
\text { significant effect on organizational } \\
\text { identity }\end{array}$ & 16,240 & 2 & Significance & Accepted \\
\hline $\begin{array}{l}\text { Islamic work ethics has a } \\
\text { significant effect on OCB }\end{array}$ & 0,311 & 2 & Not Significance & Rejected \\
\hline $\begin{array}{l}\text { Affective commitment has } \\
\text { significant effect on OCB }\end{array}$ & 3,714 & 2 & Significance & Accepted \\
\hline $\begin{array}{l}\text { Organizational identity has } \\
\text { significant effect on OCB }\end{array}$ & 4,447 & 2 & Significance & Accepted \\
\hline
\end{tabular}

\section{Discussion}

The first hypothesis, Islamic work ethics with CR 13.730 > cut of value 2 has a significant effect on affective commitment, meaning that with the increasing practice of Islamic work ethics, it will increase employees' affective commitment to the organization. The result of this study is consistent with the result of Yousef (2000) and Nizam et.al (2016).

The second hypothesis, Islamic work ethics with CR $16.240>$ cut of value 2 has a significant effect on the organizational identity, meaning that with the increase of Islamic work ethics practice, it will improve organizational identity. The result of this study proved the opinions expressed by Himam (2012) which states that the values held by members of the organization can develop as a differentiating organizational identity between one organization to another. In this study, these values are Islamic work ethics.

The third hypothesis, Islamic work ethics with CR $0.311<$ cut of value 2 has no significant and positive effect on OCB, meaning that the increase of Islamic work ethics practice will increase OCB insignificantly or it can be said that there is no influence of Islamic work ethics on OCB. The result of this study is in accordance with Alhyasat (2012) in terms of dimensions of expertise, responsibility, fairness, collaboration does not significantly influence OCB.

The fourth hypothesis, the affective commitment with CR 3.714 > cut of value 2 has a significant effect on OCB, meaning that the increase of affective commitment will increase OCB. The result of this study is in accordance with the study result by Subejo et.al (2013).

The fifth hypothesis, organizational identity with CR 4.447 > cut of value 2 has a significant effect on OCB, meaning that the increase of organizational identity will increase OCB. The result of this study is in accordance with the study result of Amini et.al (2016).

\section{Conclusion}

Islamic work ethics has a significant and positive effect on the affective commitment which means that the increase of the application or practice of Islamic work ethics will increase employees' affective commitment to the organization. Islamic work ethics has a significant and positive effect on the organizational identity, meaning that the increase of application or practice of Islamic work ethics will enhance organizational identity. Islamic work ethics has no significant effect on OCB.

Affective commitment has a significant and positive effect on $\mathrm{OCB}$, meaning that the increase of affective commitment will increase OCB behavior among employees. Organizational identity has a significant and positive effect on OCB, meaning that the increase of organizational identity will increase OCB among employees.

\subsection{Managerial Implication}

In line with Islamic work ethics, expertise is not considered too important by employees. Therefore, the organizations should be able to increase awareness of the importance of mastering expertise or strengthening the perception that capacity and expertise are very important. It can be initiated in the recruitment employees process 
which prioritizes the consideration of mastery of the person (person-job fit) beyond consideration of the suitability of value with the organization (person-organization fit). Furthermore, providing opportunities and encouraging employees to improve their expertise, for example, by holding knowledge sharing activities among employees, implementing training programs, and providing scholarships to continue to higher education or mastery of certain skills.

Regarding the identity of the organization, organizations should be able to publish information about improving infrastructure and supporting facilities both in function, capacity, and appearance to the public through effective media. Besides that, carrying out intensive public relations and external communication activities by making each employees as a "spokesperson" or "organization ambassador" and improving social assistance programs or free treatment for the community.

Related to OCB, organizations should be able to increase the initiative of each employee by encouraging them to be active in organizational knowledge management according to their level and authority, encouraging employees to be active in meetings and participate in a discussion of organizational decisions through participatory management.

Regarding effective commitment, organizations should be able to improve their sense of belonging to the organization by carrying out activities to improve their sense of family or give personal attention or appreciation, encourage the increased of togetherness among employees with employee gathering, traveling and providing opportunities for the formation of informal groups of employees based on hobbies and so forth.

\subsection{Future Research Agenda}

There needs to be replication research involving the dimensions or indicators of Islamic work ethics that are able to provide deeper and specific explanations. Future researches need to develop a more comprehensive model involving other variables such as knowledge sharing and collaboration capability related to OCB that may have a greater influence on OCB.

\section{References}

Abbasi, A. S., \& Aiza, H. R. (2012). Impact of islamic work ethics, reward system and organizational environment on citizenship behavior of employees. Sci.Int. (Lahore), 24(4), 513-519.

Ahmad, S., \& Musa, Y. O. (2012). The concept of islamic work ethic: an analysis of some points in the prophetic tradition. International Journal of Business and Social Science, 3(20).

Alhyasat, K. M. K. (2012). The role of islamic work ethics in developing organizational citizenship behavior at the Jordanian Press Foundations. Journal of Islamic Marketing, 3(2), 139-154. https://doi.org/10.1108/17590831211232555

Ali, Abbas J., \& Abdullah, A. (2008). Islamic work ethic: a critical review. Cross Cultural Management: An International Journal, 15(1), 5-19. https://doi.org/10.1108/13527600810848791

Allameh, S. M., Saeed, A., \& Ali, K. (2012). The effect of self-concept and organizational identity on organizational citizenship behavior (a case study in the social security organization of isfahan city). International Journal of Human Resource Studies, 2(1). https://doi.org/10.5296/ijhrs.v2i1.1119

Amini, M., Mehdi, A., Masoud, G., \& Mani, R. (2016). Evaluation of the relationship between social self concepts, organizational identity and organizational citizenship behavior. Asian Social Science, 12(2). https://doi.org/10.5539/ass.v12n2p62

Fakhar, H. M. Z., Muhammad, Y. K. M., Arshad, M. S., \& Muhammad, I. R. (2012). Islamic work ethics in contemporary era and its relationship with organizational citizenship behavior (a study based on hospitals and banks in Pakistan). Interdisciplinary Journal of Contemporary Research in Business, 4(6).

Ferdinand, A. (2005) Structural equation modeling in management research, Diponegoro University publishing agency: Semarang.

Ghozali, I. (2017) Structural equation models, concepts and applications with AMOS 24 update bayesian SEM, Edition 7, Diponegoro University publishing agency: Semarang.

Han, S. T., Agustinus, N., Endo, W. K., \& Thomas, S. K. (2012). Affective commitments in organizations affected by perceived organizational support and job satisfaction. Journal of Management and Entrepreneurship, 1(14).

Harper, P. J. (2015). Exploring forms of organizational citizenship behaviors (OCB): antecedents and outcomes. Journal of Management and Marketing Research, 18 - February. 
Hidayat, M. (2010). Analysis of commitments (affective, continuance and normative) towards the quality of service approval of motorized vehicle registration (empirical study in joint office of samsat in east kalimantan province). Journal of Management and Entrepreneurship, 12(1), 11-23.

Himam, F. (2012). Organizational Identity: Exploration of dimensions and their meanings for organizational change. Business Strategy Journal, 16(2), Hal .198-204.

Kusumastuti, A. F., \& Harlina, N. (2013). Affective commitment of organizations judging from perception of transactional leadership in implementing workers in public companies (perum) x semarang. Journal of Management and Organizational Studies, 10(1), Hal.13.

Nizam, S. b. S., Siti, S. b. B., Muhammad, S. A., \& Abdullah, O. (2016). The effect of islamic work ethics on organizational commitment. Procedia Economics and Finance, 35, 582-590. https://doi.org/10.1016/S2212-5671(16)00071-X

Podsakoff, P. M., Scott, B. M., Julie, B. P., \& Daniel, G. B. (2000). Organizational citizenship behavior: a critical review of theoretical and empirical literature and suggestions for future research. Journal of Management, 26(3), 513-563. https://doi.org/10.1177/014920630002600307

Prasetyo, Y. W., \& Fathul, H. (2013). Organizational identity development as a business strategy. Journal of Psychology, 40(2), .226-239.

Rhoades, L., Elsenberger, R., \& Armeli, S. (2001). Affective commitment to organization: the contribution of perceived organizational support. Journal of Applied Psychology, 86(5), 825-836. https://doi.org/10.1037/0021-9010.86.5.825

Rodhiyatun, E. W., \& Tri, N. H. (2014). Patient's perception of hospitality towards satisfaction in the inpatient room of kendal islamic hospital. Proceedings of the 2014 Central Java PPNI National Conference 2014, pp.292-297.

Subejo, E. A. T., Armanu, T., \& Siti, A. (2013). The effect of organizational commitment and organization identity strength to citizenship behavior (ocb) impact on fire department and disaster employee performance in jakarta indonesia. IOSR Journal of Business and Management (IOSR-JBM), 10(3), 30-36. https://doi.org/10.9790/487X-1033036

Wahyudi, A. (2012). The Influence of organizational commitment and islamic work ethics on the work performance of teaching staff in higher education in surakarta with the institution base as a moderator variable. Muqtasid Journal, 3(1), 73-89. https://doi.org/10.18326/muqtasid.v3i1.73-89

Yousef, D. A. (2000). Organizational commitment as a mediator of the relationship between islmic work ethic and attitudes toward organizational change. Human Relations, 53(4), 513. https://doi.org/10.1177/0018726700534003

Zahrah, N., Siti, N., Abdul, H., Shamsul, H. A. R., \& Bidayatul, A. M. K. (2016). Enhancing job performance through islamic religiosity and islamic work. International Review of Management and Marketing, 6 , Special Issue (S7), 195-198.

\section{Copyrights}

Copyright for this article is retained by the author(s), with first publication rights granted to the journal.

This is an open-access article distributed under the terms and conditions of the Creative Commons Attribution license (http://creativecommons.org/licenses/by/4.0/). 